\title{
Male aggressiveness in a polygynous ungulate varies with social and ecological context
}

\author{
Antonella Panebianco $^{1}$ (D) | Pablo F. Gregorio ${ }^{1}$ | Ramiro Ovejero ${ }^{2,3}$ | Antonela Marozzi $^{1}$ | \\ Mariel Ruiz Blanco ${ }^{4}$ | Leonardo R. Leggieri ${ }^{1}$ | Paula A. Taraborelli ${ }^{5}$ | \\ Pablo D. Carmanchahi ${ }^{1}$
}

${ }^{1}$ Grupo de Investigación de Eco-Fisiología de Fauna Silvestre (GIEFAS), INIBIOMACONICET-AUSMA-UNCo, San Martín de los Andes, Neuquén, Argentina

${ }^{2}$ Instituto de Ecología Regional, IERCONICET-UNT, Tucumán, Argentina

${ }^{3}$ Laboratorio de Ecología Conductual, Instituto de Ciencias Ambientales y Evolutivas, Facultad de Ciencias, Universidad Austral de Chile, Valdivia, Chile

${ }^{4}$ Programa Estepa Patagónica y Andina, Wildlife Conservation Society, Junin de los Andes, Argentina

${ }^{5}$ Centro Regional Buenos Aires Sur, INTA, Tres Arroyos, Argentina

\section{Correspondence}

Antonella Panebianco, Pasaje de la Paz 235, Asentamiento Universitario San Martín de los Andes, Universidad Nacional del Comahue. San Martín de los Andes, Neuquén Province 8370, Argentina.

Email:apanebianco@comahue-conicet.gob.ar

Funding information

FONDECYT-CONICYT; Consejo Nacional de Investigaciones Científicas y Técnicas; Agencia Nacional de Promoción Científica y Tecnológica; Idea Wild

\begin{abstract}
Aggression is a social behaviour which can be affected by numerous factors. The quality and quantity of food resources may play an important role in the aggressiveness of territorial ungulates as the defence of these resources influences female choice and mating opportunities. However, the relationship between food resources and aggression remains poorly understood. We assessed the ecological and social factors that influence aggression in Lama guanicoe, a territorial ungulate exhibiting resource-defence polygyny, during three periods (group-formation, mating and postmating) in the reproductive seasons of 2014 and 2016. We recorded 460 focal observations of territorial (family groups, solitary) and non-territorial (mixed and bachelor groups) males. We performed analyses at the population level (including all focal observations) and at the group level (each social unit separately), to test whether the factors that influence aggression differ at these different scales. We also identified proxies of vegetation quality as potential predictors of aggression. At the population level, we found that the presence of aggressive behaviour peaked during the mating season and that post-mating aggression may have been driven by inter-annual environmental variations. For family groups and solitary males, variables reflecting high vegetation quality/quantity were predictors of aggressive behaviour, reflecting the resource-defence strategy of this species. Conversely, for mixed-group males, aggression may be more associated with social instability and group size, although this hypothesis has yet to be tested. Our research reinforces the idea that aggression can occur in multiple contexts depending on male status (e.g. territorial or non-territorial) and contributes to our understanding of how ecological (i.e. availability of food resources) and social factors influence aggression in a territorial ungulate.
\end{abstract}

\section{KEYWORDS}

aggression, agonistic behaviour, Lama guanicoe, polygyny, resource-defence ungulates, territoriality 


\section{1 | INTRODUCTION}

Animals must adapt their physiology and behaviour to maximize fitness in response to changing environments (Wingfield et al., 2006). These adjustments require varying degrees of physiological and behavioural plasticity depending upon the extent to which the environment may change (Piersma \& Drent, 2003). A key example of a plastic behaviour is aggression, which can be expressed to maintain a territory and defend specific resources (e.g. food or mates) or to retain social status within a group to access resources (Wingfield et al., 2006). There are many classifications of aggressive behaviour (Brain, 1979; Moyer, 1968; Wingfield et al., 2006), which reinforces the idea that it is a widespread social behaviour occurring in a broad variety of contexts (e.g. territoriality, dominance, competition for resources, mating) and serving many functions (Huntingford \& Turner, 1987; Zumpe \& Michael, 2001). Aggressive encounters include both offensive and defensive behaviours and can manifest in a wide range of displays, from threats to direct attacks (Huntingford \& Turner, 1987).

Ecological factors such as seasonal changes in temperature, diurnal rhythms and distribution of food resources can all influence the development of aggressive interactions (Briffa \& Sneddon, 2010; Fattorini, et al., 2018). Theory suggests two alternative relationships between aggressiveness and forage resources. Some have hypothesized that aggression levels may increase when resources are limited (Fattorini, et al., 2018; Lucherini, 1996; Nelson, 2006; Sirot, 2000) due to increased intraspecific competition (i.e. feeding interference). Alternatively, the energy allocated to aggressive interactions could increase with the value of a disputed resource (Enquist et al., 1985, Geist, 1978; Parker, 1974). Accordingly, individuals could invest more in body growth (e.g. weaponry), mating and social behaviours when there is greater availability of food resources (Caraco, 1979; Geist, 1978; Goss-Custard et al., 1984).

Previous research on ungulates has reported that aggressiveness can be related to several factors, including food quality/quantity (Fattorini, et al., 2018; Taillon \& Côté, 2007), age (Fattorini, et al., 2018; Willisch \& Neuhaus, 2010), group size (Fattorini, et al., 2018), social hierarchy or dominance (Lovari et al., 2015; Taillon \& Côté, 2007; Ungerfeld \& Freitas-de-Melo, 2014), weapon (e.g. horns) size (Hoem et al., 2007; Jennings et al., 2004) and seasonality (Clutton-Brock et al., 1982; Pereira et al., 2005; Willisch \& Neuhaus, 2010). For territorial ungulates, most studies have focused on describing their behavioural patterns of aggression and towards non-territorial animals (Blank et al., 2015; Blank \& Yang, 2014; Corlatt et al., 2013; Hoem et al., 2007; Marino, 2012), and the correlation between aggression and reproductive success (Festa-Bianchet et al., 1990; Fryxell, 1987). These studies suggest that greater levels of aggressiveness of territorial males lead to higher frequencies of courtship behaviours and more mating opportunities, but may also incur greater costs (e.g. increased risk of injury and energy demands, reduced food intake, increased parasite loads; Corlatti et al., 2013). For territorial males, the quality and quantity of food resources can also play an important role in aggressiveness since the defence of these resources influences female choice and mating opportunities (Emlen \& Oring, 1977); however, the relationship between food resources and aggression remains poorly understood.

Guanacos (Lama guanicoe) are the largest native ungulates in South America, with a wide distribution ranging from Peru to Southern Argentina (Carmanchahi et al., 2019; Franklin, 1983; Raedeke, 1979). Guanaco populations can be either sedentary or migratory. Populations tend to be sedentary where forage resources are easily defensible, allowing territorial males to maintain their territories throughout the year. In contrast, where food and water are limited and weather conditions are adverse in some seasons, groups or individuals have seasonal territories and move collectively in large groups between summer and winter ranges (Bolgeri, 2016; Franklin, 1983; Franklin \& Fritz, 1991; Raedeke, 1979). Guanacos have a complex social organization based on resource-defence polygyny (Franklin, 1983; Raedeke, 1979; Young \& Franklin, 2004a), defined as a territorial system wherein males compete for access to food resources that are attractive to females. In this social mating system, the number of females that a male attracts is correlated with the quantity and quality of resources in its territory (Alcock, 1987; Emlen \& Oring, 1977). Male guanacos can be found in one of four types of social units: family groups, solitary territorial males, bachelor male groups and mixed non-territorial groups (Franklin, 1983; Ortega \& Franklin, 1995; see Methods for a detailed description). In both sedentary and migratory populations, these main social units are similar, with the exception that mixed groups are primarily found in migratory populations in varying proportions throughout the annual cycle (Franklin, 1983). This wild camelid has been successfully used as an ecological model of adaptation due to anatomical, physiological and behavioural traits that allow it to inhabit hostile environments (Franklin, 1983; González et al., 2006; Gregorio et al., 2019; Marino \& Baldi, 2008; Ovejero et al., 2016; Taraborelli et al., 2012).

Previous research on South American camelids found that aggression peaked during the reproductive season (Jurgensen, 1985; Vilá, 1992; Wilson \& Franklin, 1985) and that the most common aggressive display among male guanacos consisted of indirect interactions, such as ear threats (Wilson \& Franklin, 1985). It has also been found that family groups had higher rates of agonistic interactions than bachelor groups (Lucherini, 1996). In sedentary populations in Patagonia, territorial males appear to display more aggressive interactions and with a higher level of aggression than bachelors, regardless of predation risk (Marino, 2012). By contrast, in migratory populations where males form seasonal territories and groups are stable only during the reproductive season (Franklin, 1982, 1983), studies assessing aggressive behaviour have been mainly descriptive and little is known about the different factors that modulate these behaviours (Wilson \& Franklin, 1985).

In this study, we examine the relationship between ecological and social factors and aggressive behaviour in male guanacos during the reproductive season, considering three periods (group-formation, mating and post-mating; see Methods for a detailed description). We evaluate this relationship in a wild, partially migratory population by estimating different measures of behaviour, which may 
provide distinct information about the nature of social behaviour. First, because of the mating system and reproductive seasonality in migratory guanaco populations (Franklin, 1982, 1983; Young \& Franklin, 2004a), we expected that the probability and frequency of aggressive interactions between male guanacos would peak during the mating period (Prediction I) and would be higher in males from family groups because of the behaviour's reproductive significance (Prediction II). Second, because resource-defence ungulates fight for territories which contain attractive food resources for females (Emlen \& Oring, 1977; Franklin, 1983; Young \& Franklin, 2004a, 2004b), we expected that the presence and the frequency of aggressive interactions in territorial males (family groups and solitary males) would be higher in areas of greater forage quality and productivity (Prediction III), given that territorial males can invest more energy in aggressive interactions where resources are higher (Enquist et al., 1985; Geist, 1978; Parker, 1974) and that they also have priority access to females and mating. Finally, because non-territorial males (bachelors and mixed groups) do not engage in reproduction, we expect that aggression in these social units will be linked to food resources (Fattorini, et al., 2018; Sirot, 2000) and will be higher in areas of lower forage quality and productivity due to increased competition (Prediction IV).

\section{2 | METHODS}

\subsection{Ethical note}

The Directorate of Renewable Natural Resources of Mendoza Province (Resolution n ${ }^{\circ}$ : 893/2013 and 1231/2016) provided the necessary permits to study guanacos in La Payunia Reserve. This study was conducted with wild free-ranging animals and was completely observational. Observations were conducted from a pick-up truck or elevated sites and therefore no handling of animals took place.

\section{2 | Study area and population}

The study area is located in west-central Argentina (between $36^{\circ} 00^{\prime}$ and $36^{\circ} 36^{\prime} \mathrm{S}$, and $68^{\circ} 34^{\prime}$ and $69^{\circ} 23^{\prime} \mathrm{W}$ ), including the northern part of the 665,000 ha La Payunia Reserve. It is characterized by gently undulating topography and vast flatlands in combination with areas with steeper hills and volcanic outcrops (Martínez Carretero, 2004). The climate is semiarid; mean temperatures in the study area range between $6^{\circ} \mathrm{C}$ in winter and $20^{\circ} \mathrm{C}$ in summer, with a mean annual precipitation of $198 \mathrm{~mm}$ (Candia et al., 1993; Martínez Carretero, 2004). Vegetation is xerophytic, with 58\% plant cover, and corresponds to the La Payunia phytogeographic province (Martínez Carretero, 2004). Sandy plains are covered by herbaceous communities dominated by Panicum urvilleanum, Stipa speciosa and Sporobolus rigens, while slopes and basaltic scoria contain shrub communities mainly of Neosparton aphyllum and Ephedra ochreata
(Martínez Carretero, 2004). Guanacos use both types of habitats, and grasses (Panicum, Poa and Hordeum), as well as low shrubs (Hyalis and Ephedra), are important components of their diet. In addition, the proportions of plant groups (i.e. grasses and shrubs) in the guanaco diet show a positive association with changes in food availability (Puig et al., 1996, 1997). The main predator of guanacos is the puma (Puma concolor) and at La Payunia, predation is the most frequent cause of death for guanacos (Bolgeri \& Novaro, 2015). The study area holds the largest population of $L$. guanicoe of the westcentral region of Argentina, with about 26,000 individuals in spring in the northern part of the reserve (Schroeder et al., 2014). This is one of only a few guanaco populations that maintain annual migrations (Bolgeri, 2016).

Male guanacos can be found in one of four types of social units: (a) family groups composed of a territorial reproductive male, several females (2-15 individuals), and their offspring, forming highly cohesive and behaviourally synchronized units (hereafter referred to as "family groups"); (b) solitary territorial males, that defend a territory containing no other individuals, either males or females (hereafter, "solitary males"); (c) bachelor male groups comprised of non-reproductive and non-territorial males of all age classes (usually juveniles), with group size ranging from a few males to more than 50 (hereafter, "bachelor groups"); and (d) mixed non-territorial groups consisting of males and females of all ages, with variable group size, ranging from 15 to hundreds of animals (hereafter, "mixed groups") (Franklin, 1983; Ortega \& Franklin, 1995).

We considered three periods within the guanaco reproductive or territorial season (Young \& Franklin, 2004b): (a) group-formation (September-November), the time when animals that migrated begin to arrive at their spring and summer range and males separate from mixed groups to establish their territories (Fritz, 1985; Ortega, 1985; Wilson, 1982); (b) mating (December-January), considered the peak of the reproductive season, when social units are well established and births and mating occur, partially overlapping in time (Jurgensen, 1985; Young \& Franklin, 2004b); and (c) post-mating (February), considered the end of the reproductive season, when groups begin to gather and prepare for migration to the winter range (Young \& Franklin, 2004b).

\section{3 | Behavioural records}

We collected data daily from 8:00 to $20: 00 \mathrm{hr}$ over six 15-day surveys. Surveys were conducted during the reproductive season, spanning the three periods described above. On days when it was too hot (above $30^{\circ} \mathrm{C}$ ), we did not conduct observations between 12:00 and 15:00 hr, as the animals were inactive. Surveys were performed in each period at two sites located in the NE (approximately 26 ha and $30 \mathrm{~km}$ of tracks; $36^{\circ} 8^{\prime} \mathrm{S}, 68^{\circ} 48^{\prime} \mathrm{W}$ ) and NW (approximately 20 ha and $46 \mathrm{~km}$ of tracks; $36^{\circ} 4^{\prime} \mathrm{S}, 69^{\circ} 11^{\prime} \mathrm{W}$ ) of the reserve during the reproductive seasons (mid-September mid-February) of 2014 and 2016. We performed continuous focal-animal observations (Altman, 1974; Martin \& Bateson, 2007) 
of adult males belonging to different social units using a $60 \mathrm{~mm}$ spotting scope (20-60x; Bushnell Trophy XLT). At the beginning of each observation, we recorded the number of adults and offspring in the group, distinguished by body size. Groups were identified by excluding, at the beginning of each observation, individuals more than $300 \mathrm{~m}$ away from their neighbours. This was confirmed by noting animal movement during the observations (i.e. members of the same group moved together in the same direction, while the other individuals stayed in the same place or moved in another direction; Marino \& Baldi, 2008; Taraborelli et al., 2012). We performed focal observations at 200-600 m distances from the animals. This range of observation distances was a compromise between minimizing disturbance, since observing animals from a short distance can induce an escape response (Taraborelli et al., 2012), and being able to observe and distinguish different behaviours with the optical device used. As there is no conspicuous sexual dimorphism in guanacos, sex was assessed by observing the testes (Franklin, 1983), which could be detected unequivocally from these observation distances. Since there were no marked individuals, we used scars, natural spots or moulting wool patterns to identify individuals and we looked for males belonging to other groups after each focal observation to prevent observing the same individual twice, that is daily pseudo-replication. Within each survey, the location selected for observing males was changed daily in order to avoid watching the same groups on successive days and to minimize between-day pseudo-replication. Since at least a month passed between sampling periods, we considered each survey independent. When males were disturbed by our presence, observations were not initiated. We recorded 460 focal observations of 12-min duration (occasionally less when animals went out of sight for more than $30 \mathrm{~s}$ ), using a digital recorder (Panasonic RR-US551), with 97.28 observation hours in total. Adjustments in sampling time were performed during the first survey using the minimum area method (Matteucci \& Colma, 1982), which is estimated graphically and defined as the area at which the number of observed behaviours as a function of observation period reaches a plateau, or as the area at which an inflexion point of the curve is reached. According to the latter criterion, focal observations of less than 8 min were discarded ( $<85 \%$ of behaviours observed). During the observation time, we recorded all behaviours performed by the focal male. We defined aggressive interactions as all interactions between males of the same group or other groups involving a physical attack or a threat and included both direct and indirect forms of aggression (Lucherini, 1996; Wilson \& Franklin, 1985). These interactions included low, medium and high aggression-level displays (see Table 1 for a description of aggressive behaviour patterns; Vilá, 1992; Wilson \& Franklin, 1985), and were registered both when the focal male was the initiator or

\begin{tabular}{|c|c|c|}
\hline Behaviour type & Aggression level & Description \\
\hline Ear threat & Low & $\begin{array}{l}\text { The animal is standing with its head and neck } \\
\text { upright, ears down, and attentively observing } \\
\text { other animals in the area. }\end{array}$ \\
\hline Raised tail & Low & $\begin{array}{l}\text { The animal is standing or walking, with its } \\
\text { head and neck upright, and its tail raised } \\
\text { (perpendicular to the back). Occasionally, the tail } \\
\text { may lie completely on the back. This behaviour } \\
\text { can be observed in combination with the ear } \\
\text { threat display. }\end{array}$ \\
\hline Heading & Low & $\begin{array}{l}\text { Rapid upward and downward movement of the } \\
\text { head and neck. Usually lasts a few seconds. }\end{array}$ \\
\hline Chase & Medium & $\begin{array}{l}\text { The aggressor chases another male, with its head } \\
\text { down and its neck in line with the back, and tries } \\
\text { to kick and bite the opponent. }\end{array}$ \\
\hline Neckwrestle & High & $\begin{array}{l}\text { It is considered a tactic to unbalance the } \\
\text { opponent. Two individuals twist their necks, } \\
\text { sometimes accompanied by bites. }\end{array}$ \\
\hline Chest-ram & High & $\begin{array}{l}\text { Chest-to-chest frontal clash between two } \\
\text { individuals standing on their hind legs. }\end{array}$ \\
\hline Bite & High & $\begin{array}{l}\text { It includes biting at the forelegs to unbalance an } \\
\text { opponent, at the hind legs of a fleeing opponent, } \\
\text { or at the neck as a tactic to impede movement. }\end{array}$ \\
\hline Spit & High & $\begin{array}{l}\text { Common display of the Camelidae observed as a } \\
\text { subcomponent in intensive encounters. It may } \\
\text { occur with the individual standing in place or } \\
\text { combined with clashes or chases. }\end{array}$ \\
\hline Mount & High & $\begin{array}{l}\text { Sexual mount of another male, occasionally seen } \\
\text { during this study. }\end{array}$ \\
\hline
\end{tabular}

TABLE 1 Description of aggressive behaviour patterns (ethogram) in adult male guanacos. Descriptions are based on Wilson and Franklin (1985) and our observations. A classification of the aggression level of each behaviour is provided based on Vilá (1992): Low: there is no direct contact between males. Medium: the aggressive behaviour includes chases with both animals running, but no direct contact. High: there is direct contact between males 
the recipient of aggression. We subsequently used a digital audio editor to record the presence/absence of aggressive behaviour (presence was assigned when we observed at least one aggressive behaviour during the observation time) and calculate its frequency (total number of occurrences of aggressive behaviours during the observation time).

\section{4 | Ecological variables}

In each reproductive period, we identified ecological variables as factors that may have influenced aggressive behaviour. Vegetation type was categorized as grassland, shrubland or mixed steppe (low shrubland/grassland). In addition, six $500 \times 500 \mathrm{~m}$ vegetation polygons, which are representative of areas used by guanacos in the study site, were selected to estimate the following features: (a) As a correlate of plant productivity, we estimated the mean value of the Enhanced Vegetation Index (EVI) derived from 250-m Moderate Resolution Imaging Spectroradiometer (MODIS) satellite images (Ipdaac.usgs. gov; Reed et al., 1994). EVI is an enhanced version of the normalized difference vegetation index (NDVI; Pettorelli et al., 2005) and is adequate to model Patagonian steppe primary productivity, where vegetation cover is relatively low (Mohr Bell \& Siebert, 2008). Each MODIS image is the result of a 16-day composite; therefore, we processed two images to obtain a mean EVI value per period. (b) Vegetation cover (\%) was estimated using the point quadrat method (Daget \& Poissonet, 1971) to obtain a proxy of food resource availability. Three transects were surveyed in each polygon, and the cover values were averaged. (c) In each transect, vegetation samples were taken from guanacos' main forage sources (Panicum urvilleanum, Poa spp., Neosparton aphyllum; Puig et al., 1996; Puig et al., 1997). The percent nitrogen $(\% \mathrm{~N})$ of plants sampled in each transect was estimated using the micro-Kjeldahl analysis (AOAC, 1980) and then averaged to obtain a single value per polygon. We used $\% \mathrm{~N}$ as a proxy of high forage quality (Baron et al., 2002; Van der Wal et al., 2000). Given the homogeneity within each vegetation type (Martínez Carretero, 2004), we assumed that the sampled area and corresponding values provide a representative sample of the areas used by the observed male guanacos. For each focal observation, vegetation type was categorized and data were assigned from the nearest vegetation polygon, corresponding to the vegetation type where the male was found. For the latter, we registered the male's geographic location with a hand-held GPS (Garmin eTrex 10) after each focal observation and then used geographic information systems (QGis v2.18.12) to calculate the nearest vegetation polygon.

\section{5 | Statistical analyses}

To test our predictions, we performed analyses at two levels: a population level (for predictions I and II), in which we considered all focal observations ( $n=460)$; and a group level (for predictions III and IV), in which we used different models for family groups ( $n=114)$, solitary males $(n=281)$ and mixed groups $(n=42)$. We did not fit models for bachelor groups due to low sample size $(n=23)$.

At both levels, we selected a sequential analysis approach that allowed us to integrate information from all the focal observations (Table S1; Mulero-Pázmány et al., 2017). First, we examined which factors determined the presence/absence of aggressive behaviour in male guanacos. For this, generalized linear models (McCullagh \& Nelder, 1989) were fitted with a binomial error distribution and a logit link function. Next, we focused only on the observed males showing aggressive behaviour responses and analysed the frequency of these behaviours. We fitted generalized linear mixed models with a Poisson error distribution and log link function. We used total observation time (i.e. how long the individual was observed, expressed in minutes and log-transformed) of the focal observations as an offset to account for the different observation lengths for different males. We also used an observation level as a random factor to control for overdispersion. This term models the extra-Poisson variation in the response variable using a random effect with a unique level (id) for every data point (Harrison, 2014).

Initially, the predictor variables considered in the models at the population level were reproductive period (group-formation, mating, post-mating), sampling year $(2014,2016)$, site (NE, NW), mean EVI (range $=0.057-0.131$ ) and type of social unit (solitary, family, bachelor, mixed). We also considered the interactions period*sampling year and mean $\mathrm{EVI}^{*}$ sampling year to account for environmental variability between years, as the study site experiences high inter-annual variability (Candia et al., 1993; Martínez Carretero, 2004); period*social unit, considering that aggressive interactions during the three periods of the reproductive season could be manifested in different ways in territorial and non-territorial males; and mean EVI*social unit, to assess whether aggression in territorial and non-territorial males can be differentially influenced by resource availability (Table S1).

At the group level, we initially considered reproductive period, sampling year, site, mean EVI, \% vegetation cover (range = 33.6796.67), \%N (range $=0.120-1.713$ ) and vegetation type (shrubland, grassland, mixed steppe) as predictor variables to analyse how ecological features may affect aggressive interactions in territorial males (family groups and solitary males) and non-territorial males (mixed groups). We only considered the interaction period*sampling year in the binomial models developed for the solitary males because of the relatively low sample size of the other social units (Table S1).

We evaluated the multicollinearity of predictor variables by calculating the generalized variance inflation factor (GVIF; Fox \& Monette, 1992), which is a generalization of the variance inflation factor (VIF). GVIF is applied to measure the collinearity among covariates, such as dummy regressors from a categorical variable. Fox and Monette (1992) suggest reporting the adjusted generalized variance inflation factors AGVIF $=$ GVIF $^{1 /(2 d f)}$, where $d f$ is the number of degrees of freedom associated with the term and is analogous to reporting the square root of the VIF for a single coefficient. As a rule of thumb, AGVIF values greater than 2.236 (analogous to VIF > 5) were considered an indication of collinearity (Zuur et al., 2007). At the population level, we excluded the terms mean EVI*sampling 
year $(A G V I F=7.60)$, mean $E V I *$ social unit $(A G V I F=3.10)$ and mean EVI (AGVIF = 3.23) from the binomial model. We excluded the terms mean $\mathrm{EVI}^{*}$ sampling year $(\mathrm{AGVIF}=7.96)$, mean $\mathrm{EVI}$ *social unit (AGVIF $=3.24)$, mean EVI (AGVIF $=2.63$ ) and social unit*period $(A G V I F=2.49)$ from the frequency model. At the group level, we excluded the term vegetation cover from all the binomial models since AGVIF > 2.236. Mean EVI was also excluded from the binomial models for solitary males (AGVIF $=3.42$ ) and mixed groups (AGVIF = 7.50). We excluded mean EVI from the frequency models performed for family groups $(A G V I F=2.41)$ and solitary males (AGVIF = 2.59). Due to the low sample size at the group level, we also considered exploratory analyses between independent and response variables and model fit to include the predictors in the models (Table S1).

We used a Bayesian framework with non-informative priors to obtain $95 \%$ credible intervals $(\mathrm{Crl})$ around the mean, representing the uncertainty around our estimates. We considered an effect to be statistically meaningful when the posterior probability of the mean difference between compared estimates was higher than 0.95 or when the estimated $\mathrm{Crl}$ did not include zero (for further details on statistical inference, see Korner-Nievergelt et al., 2015). We also analysed model residuals using graphical methods (i.e. qqplots of residuals fitted values versus residuals) for homogeneity of variance or other departures from model assumptions and model fit. All modelling was performed with the software R v3.4.3 (R Core Team, 2016), using the packages "car" (Fox \& Weisberg, 2019), "bbmle" (Bolker, 2017), "Ime4" (Bates et al., 2018) and "arm" (Gelman et al., 2018).

\section{3 | RESULTS}

\section{1 | Factors influencing aggressive behaviour at the population level}

The probability of aggressive behaviour in males was greater during the mating period, compared to the group-formation period (Figure 1a; Table 2). In the mating and post-mating periods, the presence of aggressive behaviour was higher in 2014 than in 2016 (Figure 1a; Table 2). There were no differences in aggressive behaviour between sites (Table 2). In addition, the presence of aggressive behaviour was higher in males from family groups and mixed groups, compared with solitary males (Figure $1 \mathrm{~b}$; Table 2). The interaction between period and type of social unit was not meaningful (Figure S1; Table 2). The frequency of aggressive interactions in males was similar during the group-formation and the mating periods (Figure 1c; Table 2 ) and across sites (Table 2). In the post-mating period, the frequency of aggressive interactions was higher in 2014 than in 2016 (Figure 1c; Table 2). In addition, the frequency of aggressive behaviour was higher in males from family groups and mixed groups, compared to solitary males (Figure 1d; Table 2).
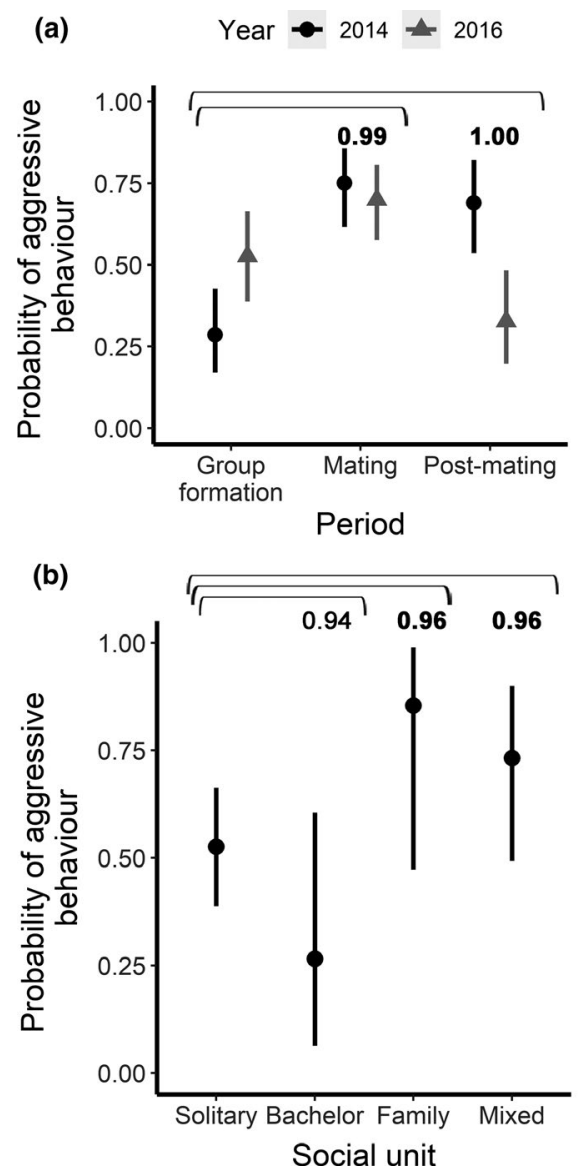

(c)

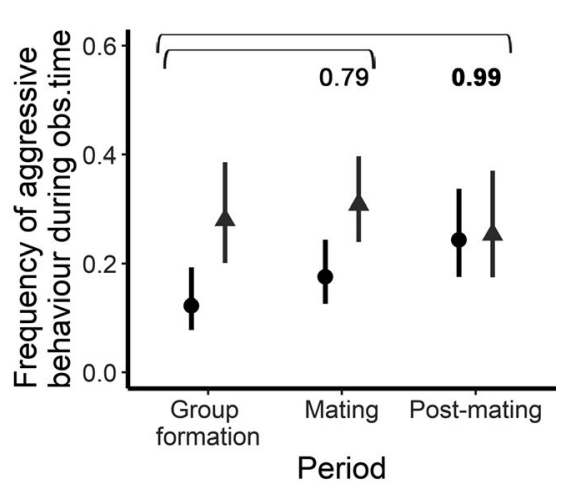

(d)

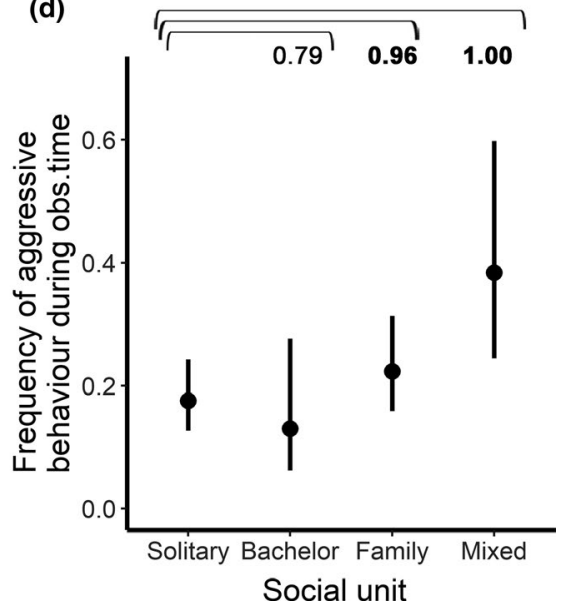

FIGURE 1 Relationship between the probability/ the frequency of aggressive behaviour during the observation time and the period of the reproductive season and the year sampled (a; c), and the social unit of the observed males (b; d). Black dots and grey triangles represent mean estimates of the models; the vertical bars represent the $95 \% \mathrm{Crl}$. Numbers represent the posterior probability of a mean difference between compared estimates. A statistically meaningful effect (presented in bold) can be assumed when the posterior probability of the mean difference between compared estimates is higher than 0.95 
TABLE 2 Results from linear models estimating the effects of predictors on the presence and frequency of aggressive behaviour in male guanacos. We present estimates of the parameters with their 95\% credible intervals $(\mathrm{Crl})$ in parentheses. A statistically meaningful effect of a fixed factor (presented in bold) can be assumed when the posterior probability (Post P.) of the mean difference between compared estimates is higher than 0.95 or when the estimated $\mathrm{Crl}$ does not include zero

\begin{tabular}{|c|c|c|c|c|}
\hline \multirow[b]{2}{*}{ Predictors } & \multicolumn{2}{|c|}{$\begin{array}{l}\text { Presence of aggressive } \\
\text { behaviour }\end{array}$} & \multicolumn{2}{|c|}{$\begin{array}{l}\text { Frequency of aggressive } \\
\text { behaviour }\end{array}$} \\
\hline & $\begin{array}{l}\text { Estimate }(95 \% \\
\text { Crl) }\end{array}$ & Post P. & $\begin{array}{l}\text { Estimate }(95 \% \\
\text { Crl) }\end{array}$ & $\begin{array}{l}\text { Post } \\
\text { P. }\end{array}$ \\
\hline Intercept & $\begin{array}{l}-0.94(-1.58 \\
-0.29)\end{array}$ & 0.99 & $\begin{array}{l}-2.09(-2.55 \\
-1.64)\end{array}$ & 1.00 \\
\hline Year:2016 ${ }^{\mathrm{a}}$ & $1.04(0.29 ; 1.79)$ & 0.99 & $0.82(0.30 ; 1.35)$ & 0.99 \\
\hline Period: mating ${ }^{\mathrm{b}}$ & $2.07(1.25 ; 2.89)$ & 1.00 & $0.36(-0.15 ; 0.86)$ & 0.91 \\
\hline Period: post-mating & $1.77(0.91 ; 2.64)$ & 0.99 & $0.68(0.17 ; 1.21)$ & 0.99 \\
\hline Site: $\mathrm{NE}^{\mathrm{c}}$ & $\begin{array}{l}-0.19(-0.62 \\
0.23)\end{array}$ & 0.81 & $0.13(-0.10 ; 0.36)$ & 0.86 \\
\hline Social unit: bachelor ${ }^{d}$ & $\begin{array}{l}-1.26(-2.85 \\
0.32)\end{array}$ & 0.94 & $\begin{array}{l}-0.30(-1.00 \\
0.42)\end{array}$ & 0.79 \\
\hline Social unit: family ${ }^{d}$ & $\begin{array}{l}2.11(-0.20 \\
4.38)\end{array}$ & 0.96 & $0.24(-0.02 ; 0.51)$ & 0.96 \\
\hline Social unit: mixed ${ }^{d}$ & $0.97(-0.13 ; 2.07)$ & 0.96 & $0.78(0.45 ; 1.11)$ & 1.00 \\
\hline Year:2016*Period:mating & $\begin{array}{l}-1.32(-2.33 \\
-0.29)\end{array}$ & 0.99 & $\begin{array}{l}-0.26(-0.88 \\
0.36)\end{array}$ & 0.79 \\
\hline Year:2016*Period: post-mating & $\begin{array}{l}-2.62(-3.69 \\
-1.53)\end{array}$ & 1.00 & $\begin{array}{l}-0.78(-1.48 \\
-0.10)\end{array}$ & 0.99 \\
\hline $\begin{array}{l}\text { Period: mating*social unit: } \\
\text { bachelor }\end{array}$ & $1.43(-1.36 ; 4.27)$ & 0.84 & -- & -- \\
\hline $\begin{array}{l}\text { Period: post-mating*social unit: } \\
\text { bachelor }\end{array}$ & $1.15(-1.36 ; 3.71)$ & 0.81 & -- & -- \\
\hline Period: mating*social unit: family & $\begin{array}{l}-1.94(-4.28 \\
0.48)\end{array}$ & 0.94 & -- & -- \\
\hline $\begin{array}{l}\text { Period: post-mating*social unit: } \\
\text { family }\end{array}$ & $\begin{array}{l}-1.75(-4.14 \\
0.71)\end{array}$ & 0.92 & -- & -- \\
\hline Period: mating*social unit: mixed & $\begin{array}{l}-0.12(-2.05 \\
1.80)\end{array}$ & 0.54 & -- & -- \\
\hline $\begin{array}{l}\text { Period: post-mating*social unit: } \\
\text { mixed }\end{array}$ & $\begin{array}{l}2.02(-0.44 \\
4.44)\end{array}$ & 0.94 & -- & -- \\
\hline
\end{tabular}

aReference level of "Year" variable: 2014.

${ }^{b}$ Reference level of "Period" variable: group-formation.

'Reference level of "Site" variable: NW.

${ }^{\mathrm{d}}$ Reference level of "Social unit" variable: solitary male.

\subsection{Factors influencing aggressive behaviour at the group level}

The probability of aggressive behaviour in territorial males (family groups and solitary males) was influenced by some of the ecological variables tested (Figure 2; Table 3). In males from family groups, \%N of vegetation had no ecologically meaningful effect on the probability of aggressive behaviour (Figure 2a; Table 3). In contrast, aggressive behaviour increased with greater mean EVI (Table 3). In solitary males, the presence of aggressive behaviour increased in areas with higher $\% \mathrm{~N}$ of the vegetation (Figure $2 \mathrm{~b}$; Table 3). In solitary males, the presence of aggressive behaviour was also lower in grasslands compared to shrublands (Table 3). In the case of non-territorial males (i.e. mixed groups), the $\% \mathrm{~N}$ did not influence the probability of aggressive behaviour (Figure 2c; Table 3).
The frequency of aggressive behaviour in males from family groups was higher in grasslands, compared to shrublands (Table 4). In contrast, neither \% $\mathrm{N}$ nor vegetation cover influenced the frequency of aggression (Figure 3a,b, Table 4). In solitary males, the frequency of aggressive interactions increased with higher vegetation cover, while $\% \mathrm{~N}$ had no ecologically meaningful effect (Figure 3c,d; Table 4). In the case of mixed groups, the frequency of aggressive interactions was not affected by any of the ecological variables examined (Figure 3e,f; Table 4).

\section{4 | DISCUSSION}

\subsection{Aggressive behaviour at the population level}

Our results showed that aggressive interactions in male guanacos varied among the group-formation, mating and post-mating periods, 

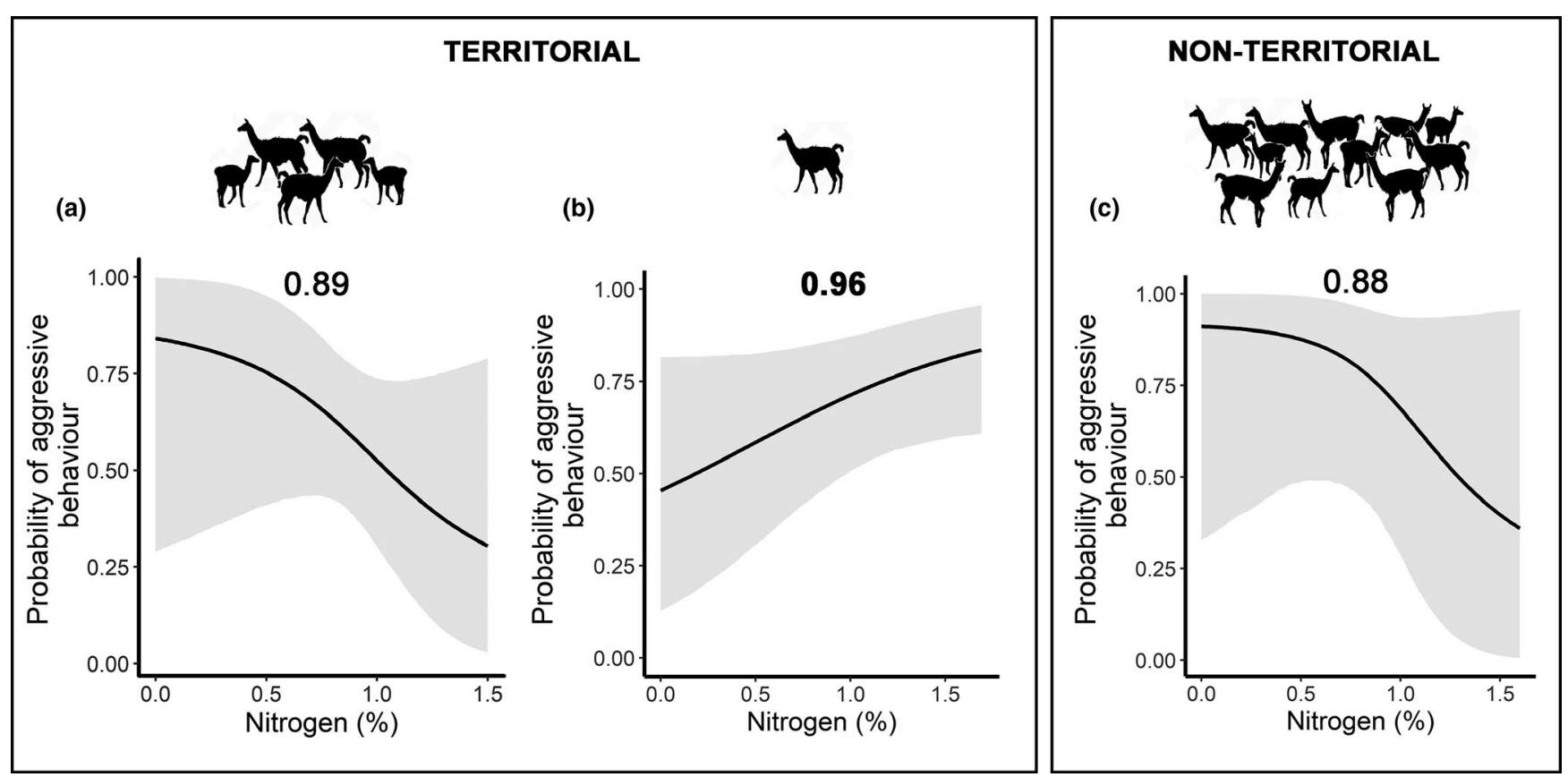

FIGURE 2 Relationship between the probability of aggressive behaviour and the percentage of nitrogen in plants in males belonging to different social units. We used different models for each social unit: males from family groups (a), solitary males (b) and males from mixed groups (c). Black lines represent mean estimates of the models, and grey bands represent $95 \% \mathrm{Crl}$. Numbers represent the posterior probability of a mean difference between compared estimates. A statistically meaningful effect (presented in bold) can be assumed when the posterior probability of the mean difference between compared estimates is higher than 0.95

suggesting that seasonality during the reproductive season is an important determinant of variation in this social behaviour. The presence of aggressive behaviour peaked during the mating period, as we predicted (Prediction I). These findings are similar to those found in other populations of guanacos in Chile and Argentina, especially for territorial males (Marino, 2012; Wilson \& Franklin, 1985). Moreover, a wide variety of vertebrate taxa display similar patterns, including other wild South American camelids (Vicugna vicugna, Vilá, 1992), ungulates (Antilocapra americana, Kitchen, 1974; Cervus elaphus, Clutton-Brock et al., 1982; Aepyceros melampus, Murray, 1982; Gazella subgutturosa, Blank et al., 2015), primates (Cavigelli \& Pereira, 2000; Ostner et al., 2002) and birds (Wingfield et al., 1987, 2001).

Contrary to our expectations, the frequency of aggressive interactions did not differ between the group-formation and the mating periods (Figure 1c). Previous research in South American camelids has reported contrasting results. Studies carried out in another migratory guanaco population in southern Patagonia reported that the rate of aggressive encounters between territorial males was higher in December, during the mating period, compared to January or February (Jurgensen, 1985). However, aggression rates between group-formation and the mating periods were not contrasted. On the other hand, Vila (1992) reported similar results to those found in our study regarding the frequency of aggressive behaviours in vicuñas. The similar frequency of aggressive interactions between these two periods could be related to male defence of territories during the reproductive season, which begins during the group-formation period and continues through the mating period.
Considering that aggressiveness is influenced by resource availability (Fattorini, et al., 2018; Sirot, 2000; Taillon \& Côté, 2007), the difference in aggressive behaviour between 2014 and 2016 during the group-formation and post-mating periods could be due to inter-annual environmental variability and differences in forage availability. During the reproductive season of 2014 , primary productivity and vegetation cover were $26.2 \%$ lower than in the reproductive season of 2016 (see Tables S2 and S3) and this difference could have led to greater competition for forage in 2014. In this sense, the increased presence and frequency of aggressive behaviour observed during the 2014 post-mating period could have been more related to competition for forage than to reproductive concerns, irrespective of males' social unit. The nearly complete absence of copulations during the post-mating period supports this argument (Jurgensen, 1985; Panebianco, 2019; Young \& Franklin, 2004b). Further evidence in favour of this argument comes from the relatively high concentration of faecal cortisol metabolites observed in guanaco males during the post-mating period of 2014 (Panebianco, 2019), suggesting that individuals had higher energy demands during this time (Gregorio et al., 2019; Romero et al., 2009). Similarly, in other ungulate species, such as Apennine chamois (Rupicapra pyrenaica ornata) and white-tailed deer (Odocoileus virginianus), food depletion influenced intraspecific social behaviour by increasing aggression (Fattorini, et al., 2018; Taillon \& Côté, 2007) and endocrine correlates (Fattorini, et al., 2018), in accordance with competition theory (Sirot, 2000).

Our results supported that aggressive behaviour is higher in males from family groups (Prediction II). Both the probability and the frequency of aggressive behaviour were higher in males 
TABLE 3 Results from linear models estimating the effects of predictors on the presence of aggressive behaviour in male guanacos belonging to different social units. We used different models for each social unit. We present estimates of the parameters with their $95 \%$ credible intervals ( $\mathrm{Crl}$ ) in parentheses. A statistically meaningful effect of a fixed factor (presented in bold) can be assumed when the posterior probability (Post P.) of the mean difference between compared estimates is higher than 0.95 or when the estimated Crl does not include zero

\begin{tabular}{|c|c|c|c|c|c|c|}
\hline Predictors & \multicolumn{4}{|l|}{ Territorial males } & \multicolumn{2}{|c|}{$\frac{\text { Non-territorial males }}{\text { Mixed group }}$} \\
\hline Intercept & $-5.42(0.07 ; 10.79)$ & 0.98 & $-2.22(-4.17 ;-0.31)$ & 0.99 & $5.29(-2.38 ; 12.89)$ & 0.91 \\
\hline Period: post-mating & $-3.90(-7.39 ;-0.46)$ & 0.99 & $1.85(0.35 ; 3.34)$ & 1.00 & $1.97(-0.54 ; 4.49)$ & 0.94 \\
\hline Site: $\mathrm{NE}^{\mathrm{C}}$ & $-0.72(-1.71 ; 0.27)$ & 0.92 & $0.27(-0.36 ; 0.89)$ & 0.80 & -- & -- \\
\hline Mean EVI & $\begin{array}{l}69.33(14.00 \\
124.71)\end{array}$ & 0.99 & -- & -- & -- & -- \\
\hline Year:2016*Period:mating & -- & -- & $-1.75(-3.06 ;-0.41)$ & 0.99 & -- & -- \\
\hline Year:2016*Period: post-mating & -- & -- & $-3.24(-4.63 ;-1.87)$ & 1.00 & -- & -- \\
\hline
\end{tabular}

a Reference level of "Year" variable: 2014.

${ }^{\mathrm{b}}$ Reference level of "Period" variable: group-formation.

${ }^{\mathrm{c}}$ Reference level of "Site" variable: NW.

d'Reference level of "vegetation type" variable: shrubland.

TAB LE 4 Results from linear models estimating the effects of predictors on the frequency of aggressive behaviour in male guanacos belonging to different social units. We used different models for each social unit. We present estimates of the parameters with their 95\% credible intervals ( $\mathrm{Crl}$ ) in parentheses A statistically meaningful effect of a fixed factor (presented in bold) can be assumed when the posterior probability (Post P.) of the mean difference between compared estimates is higher than 0.95 or when the estimated $\mathrm{Crl}$ does not include zero

\begin{tabular}{|c|c|c|c|c|c|c|}
\hline \multirow{2}{*}{ Predictors } & \multicolumn{4}{|l|}{ Territorial males } & \multirow{2}{*}{\multicolumn{2}{|c|}{$\begin{array}{l}\text { Non-territorial males } \\
\text { Mixed group }\end{array}$}} \\
\hline & \multicolumn{2}{|l|}{ Family group } & \multicolumn{2}{|l|}{ Solitary male } & & \\
\hline Intercept & $-1.92(-3.54 ;-0.26)$ & 0.99 & $-1.99(-2.87 ;-1.14)$ & 1.00 & $-0.87(-2.78 ; 1.03)$ & 0.81 \\
\hline Period: post-mating & $0.22(-0.81 ; 1.22)$ & 0.67 & $0.29(-0.14 ; 0.73)$ & 0.90 & -- & -- \\
\hline Vegetation cover & $0.01(-0.01 ; 0.01)$ & 0.53 & $0.01(-0.00 ; 0.02)$ & 0.97 & $0.02(-0.01 ; 0.04)$ & 0.85 \\
\hline Nitrogen percentage & $0.24(-0.86 ; 1.34)$ & 0.66 & $-0.08(-0.56 ; 0.73)$ & 0.59 & $-0.36(-1.64 ; 0.93)$ & 0.70 \\
\hline $\begin{array}{l}\text { Vegetation type: mixed } \\
\text { steppe }^{d}\end{array}$ & $0.21(-0.33 ; 0.74)$ & 0.77 & $-0.22(-0.67 ; 0.23)$ & 0.83 & -- & -- \\
\hline
\end{tabular}

${ }^{a}$ Reference level of "Year" variable: 2014.

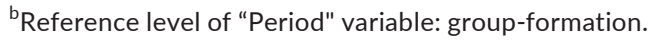

'Reference level of "Site" variable: NW.

${ }^{\text {d}}$ Reference level of "vegetation type" variable: shrubland. 


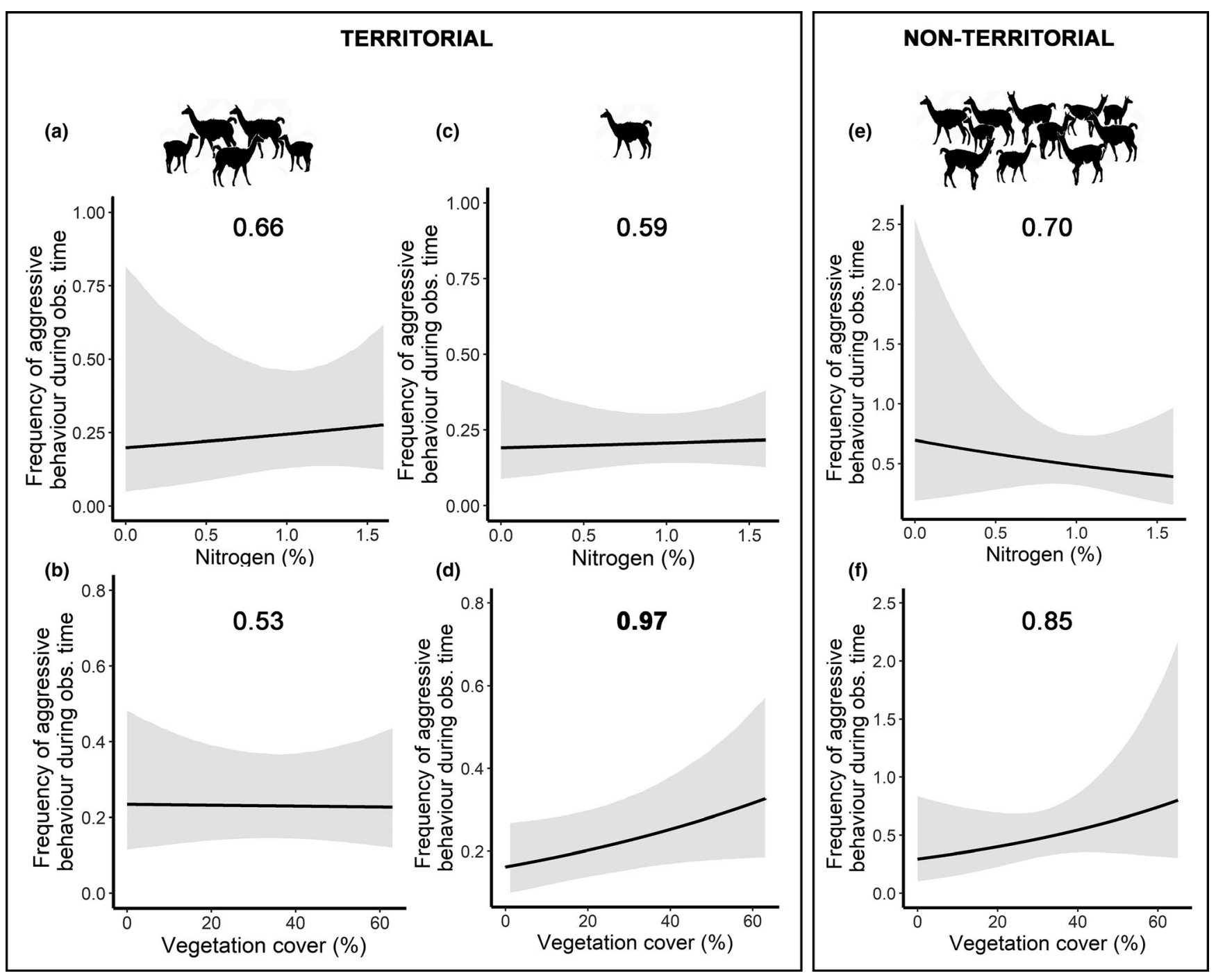

FIGURE 3 Relationship between the frequency of aggressive behaviour during the observation time, the percentage of nitrogen in plants and vegetation cover in males belonging to different social units. We used different models for each social unit: males from family groups $(a, b)$, solitary males (c, d) and males from mixed groups (e, f). Black lines represent mean estimates of the models, and grey bands represent $95 \% \mathrm{Crl}$. Numbers represent the posterior probability of a mean difference between compared estimates. A statistically meaningful effect (presented in bold) can be assumed when the posterior probability of the mean difference between compared estimates is higher than 0.95

from family groups. Similar results were found in previous studies (Lucherini, 1996; Marino, 2012) and likely reflect the social organization of wild South American camelids, where families defend food resources and therefore play a main role in aggressive interactions within the population. In accordance with Lucherini (1996), our data also suggest that family groups of wild South American camelids, at least during the summer (i.e. reproductive season), live in a stable and predictable social environment in which superfluous agonistic interactions between males are avoided, as they are energetically costly and potentially dangerous (guanacos and vicuñas can use canines teeth during fights). In fact, in our study, males from family groups did not engage in high aggression-level displays (Table 1) and performed mostly low to medium aggression-level behaviours, such as ear threats or chases. These indirect displays may be sufficient for the defence of territories in this social context. Additionally, males may use other strategies that could be equally successful, such as active vigilance (i.e. social vigilance; Marino \& Baldi, 2008), which has been recorded in other ungulate species (Kitchen, 1974; Maher, 2000).

Alternatively, phenotypic traits (e.g. antler size, body mass, body size, colour) are commonly used in ungulates as signals of rank in agonistic behaviour to assess fighting ability of opponents (CluttonBrock \& Albon, 1979; Hoem et al., 2007; Lovari et al., 2015; Taillon \& Côté, 2007; West \& Packer, 2002; Zahavi, 1987). Guanacos may retain some kind of rank signal, like body mass or colour (Lovari et al., 2015), that allows low-ranking individuals to avoid territorial males without the need to involve in high aggression-level interactions. However, this hypothesis has yet to be tested.

Despite the energy costs of aggression (Clutton-Brock et al., 1979; Huntingford \& Turner, 1987), males from family groups frequently engaged in aggressive interactions. These repeated aggressive displays could be interpreted as signals of individual 
condition. Territorial and top-ranking males of many species signal their individual quality and fighting ability to other competitors through repetitive aggressive displays even in stable social groups (Parker, 1974; Payne \& Pagel, 1997), including goitered gazelle (Blank et al., 2015), Himalayan tahr (Hemitragus jemlahicus; Lovari et al., 2015) and goats (Capra hircus; et al., 2000). This behaviour is also a cue of their willingness to fight, which can affect the decision-making processes of the other males involved (Blank et al., 2015).

The probability and frequency of aggressive interactions in males from mixed groups was also high, which was unexpected. These results could be related to many factors such as group size and composition (i.e. different age/sex class), and social instability. In our study, mixed groups had a mean size of 42 individuals (Figure 4) and contained multiple adult males. In this scenario, the encounter rate among individual animals (e.g. competitors and potential mates) is likely high (Knell, 2009; Vander Wal et al., 2012), leading to an increase in aggressive encounters and intrasexual competition. Additionally, it could be argued that mixed groups during the reproductive season are socially unstable units and lack a social hierarchy, because the composition and size of these associations can vary considerably in the short term, as animals can come and go at will, and they are remnant groups from migration. Consequently, this social instability could induce higher levels of aggressiveness (Teichroeb \& Sicotte, 2008). Similarly, studies in other ungulate species reported that aggressiveness was enhanced after regrouping experiments (goats, Andersen et al., 2008; Ozotoceros bezoarticus, Villagrán et al., 2020). The lack of stable social bonds and changes in group composition may have negative consequences, such as reduced access to food resources (Andersen et al., 2008) and lower food intake and growth (Stookey \& Gonyou, 1994), so further research is needed to assess the potential consequences of aggression in mixed groups.

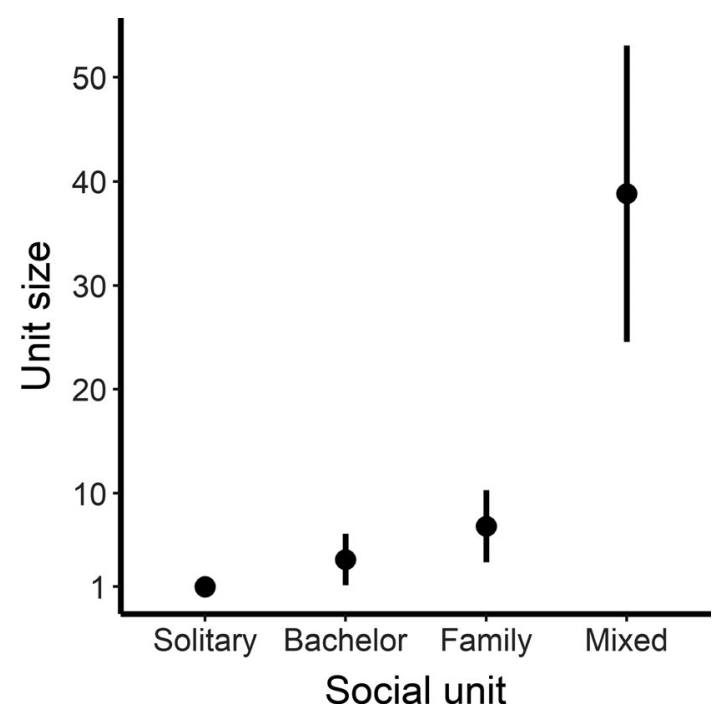

FIGURE 4 Mean \pm standard deviation of unit size in relation to the social unit to which the focal males belonged

\subsection{Aggressive interactions at the group level}

Our results showed that the probability and the frequency of aggressive interactions increased with higher quantity (higher mean $\mathrm{EVI}$; higher vegetation cover) and/or quality (higher \% $\mathrm{N}$ of vegetation) of food resources in territorial males (partially supporting Prediction III), but not in non-territorial males (Tables 3 and 4). In general, most aggressive interactions relate to conflict over food and mating, and territoriality is often a combination of these two contexts (Parker, 1974). If we also consider that one of the main drivers of fighting behaviour in males is resource value and that animals adjust fighting to variation in resource value (Arnott \& Elwood, 2008; Barroso et al., 2000; Koenig et al., 2004; Taillon \& Côté, 2007), the defence of high-quality food resources by territorial male guanacos may provide access to better forage and enhance probability of mating with females in their territory. This possibility may also apply to solitary males. Although solitary males are not associated with other individuals, they were seen copulating with females at least as often as males from family groups (Panebianco et al., 2020). In this sense, resource value may be influenced by both extrinsic factors linked to absolute properties of the resource unit (i.e. forage quality), and intrinsic factors related to the subjective value an individual assigns to the resource (i.e. mating opportunity) (Enquist \& Leimar, 1987; Lane $\&$ Briffa, 2018). Accordingly, as the value of the resource increases, so does the cost that an animal is willing to pay for that resource, for example, in terms of contest duration or energy allocation (Arnott \& Elwood, 2008; Enquist \& Leimar, 1987; Maynard Smith, 1982). This trade-off should be the subject of future research because it may improve our understanding of the adaptive value aggressive behaviour.

The relationship between resource value and aggressiveness has been studied and confirmed in other species (Barroso et al., 2000; Clutton-Brock et al., 1979; Fattorini, et al., 2018; Hoem et al., 2007). For instance, when nursing effort is the highest, female Apennine chamois select nutritious food patches to cope with the heavy energetic demands. This in turn leads to increased rates of aggression (Fattorini, et al., 2018). In this way, our study in guanacos combined with previous evidence suggests that differences in the assessment of resources are related to mating strategies (i.e. harem-defence or resource-defence) and the resource at stake (Jennings \& Gammell, 2013). A potential caveat is that sample sizes at the group level were relatively small. Further research evaluating the intrinsic (e.g. male age) and extrinsic (e.g. size and quality of the territory assessed by measuring other attributes such as fibre content or crude protein) factors influencing value of resources (Lane \& Briffa, 2018) in territorial male guanacos is needed to better understand potential impacts on aggressive behaviour.

In contrast to Prediction IV, aggression in non-territorial mixed groups was not associated with the quality and/or quantity of food resources, and this may be because competitive interactions between individuals are not expected to increase when food is abundant (Sirot, 2000), as they are during the reproductive season. A lack of an association between aggressive behaviour and high availability of food resources has been reported in guanacos previously 
(Marino, 2012). In this sense, the greater aggressiveness recorded in mixed sex groups at the population level may not be associated with contest over food. While this aggressiveness may be due to social instability and group size, as previously discussed, further research will be necessary to understand in more depth the factors affecting aggression in these social units. For instance, the assessment of aggressive interactions outside the reproductive season, when mixed groups comprise a large proportion of the population and forage resources decrease, could further clarify the relationships among these factors.

\section{5 | CONCLUSIONS}

We assessed ecological and social factors that could influence aggressive interactions in male guanacos using different measures of behaviour. At the population level, our results revealed that the presence of aggressive interactions peaks during the mating season and that aggressiveness might vary with inter-annual environmental fluctuations. At the group level, our results showed that the factors influencing aggression might be different for territorial and non-territorial males. For family groups and solitary males, high food resource quality and/or quantity were predictors of aggressive interactions, findings that may be related to the resource-defence strategy of this species. Conversely, male aggression in mixed sex groups may be associated with social instability and group size. Overall, our research reinforced the hypothesis that aggression can occur in multiple contexts depending on male status (e.g. territorial or non-territorial), and contributed to our understanding of how food availability and social factors influence aggression in a resource-defence ungulate. Further research is needed to better understand the relationship between territoriality, resource value assessment and reproduction in wild guanacos.

Relatively little effort has been devoted to understanding how ecological factors influence aggression in resource-defence ungulates compared to other mating systems (e.g. harem-defence). Thus, our research represents an important contribution to the study of this social behaviour during the reproductive season.

\section{ACKNOWLEDGEMENTS}

The Directorate for Renewable Natural Resources of Mendoza Province (Resolution n ${ }^{\circ}$ : 893/2013 and 1231/2016) provided the necessary permits to work in La Payunia Reserve. We would like to thank the park rangers and field assistants for providing logistical support for fieldwork, and Lucía Mentesana and Lucila Herbert for their comments on previous versions of the manuscript. We also thank Julia D. Monk and Mary Rowland for their support in checking the English writing style. This study was supported by IDEA WILD, ANPCYT (PICT-1305/ PICT-0304), CONICET (PIP-11220100100386) and FONDECYT-CONICYT-PROGRAM (No. 3140237).

\section{ORCID}

Antonella Panebianco (iD https://orcid.org/0000-0001-7900-1118

\section{REFERENCES}

Alcock, J. (1987). The effects of experimental manipulation of resources on the behavior of two calopterygid damselflies that exhibit resource-defense polygyny. Canadian Journal of Zoology, 65, 24752482. https://doi.org/10.1139/z87-374

Altman, J. (1974). Observational study of behavior: Sampling methods. Behaviour, 49, 227-267. https://doi.org/10.1163/156853974X00534

Andersen, I. L., Roussel, S., Ropstad, E., Braastad, B. O., Steinheim, G., Janczak, A. M., Jørgensen, G. M., \& Bøe, K. E. (2008). Social instability increases aggression in groups of dairy goats, but with minor consequences for the goats' growth, kid production and development. Applied Animal Behaviour Science, 114(1-2), 132-148. https:// doi.org/10.1016/j.applanim.2008.01.007

AOAC. (1980). Official Methods of Analysis (W. Horwitz, Ed.). : Association of Official Analytical Chemists.

Arnott, G., \& Elwood, R. W. (2008). Information gathering and decision making about resource value in animal contests. Animal Behaviour, 76, 529-542. https://doi.org/10.1016/j.anbehav.2008.04.019

Baron, V. S., Mapfumo, E., Dick, A. C., Naeth, M. A., Okine, E. K., \& Chanasyk, D. S. (2002). Grazing intensity impacts on pasture carbon and nitrogen flow. Journal of Range Management, 55(6), 535-541. https://doi.org/10.2307/4003996

Barroso, F. G., Alados, C. L., \& Boza, J. (2000). Social hierarchy in the domestic goat: Effect on food habits and production. Applied Animal Behaviour Science, 69(1), 35-53. Retrieved from www.elsevier.comrl ocaterapplanim https://doi.org/10.1016/S0168-1591(00)00113-1

Bates, D., Maechler, M., Bolker, B., Walker, S., Haubo, R., Christensen, B., Green, P., \& Fox, J.(2018). Linear Mixed-Effects Models using "Eigen" and S4. Retrieved from http://dk.archive.ubuntu.com/pub/ pub/cran/web/packages/Ime4/Ime4.pdf

Blank, D. A., Ruckstuhl, K., \& Yang, W. (2015). Seasonal dynamics of agonistic displays in territorial and non-territorial males of goitered gazelle. Zoology, 118(1), 63-68. https://doi.org/10.1016/j. zool.2014.08.004

Blank, D. A., \& Yang, W. (2014). Does social status of males change their aggressive behavior repertoire in goitered gazelle (Gazella subgutturosa guld., 1780)? Behavioural Processes, 108, 20-26. https://doi. org/10.1016/j.beproc.2014.09.017

Bolgeri, M. J. (2016). Caracterización de movimientos migratorios en guanacos (Lama guanicoe) y patrones de depredación por pumas (Puma concolor) en la Payunia, Mendoza. [Doctoral dissertation, Universidad Nacional del Comahue]. Retrieved from http://rdi.uncoma.edu.ar/handle/123456789/164

Bolgeri, M. J., \& Novaro, A. J. (2015). Variación espacial en la depredación por puma (Puma concolor) sobre guanacos (Lama guanicoe) en la Payunia, Mendoza. Argentina. Mastozoología Neotropical, 22(2), 255-264.

Bolker, B. M. (2017). Tools for general maximum likelihood estimation. Cran R Project, 1-29. Retrieved from https://cran.r-project.org/packa ge $=$ bbmle

Brain, P. (1979). Hormones, drugs and aggression. Annual Research Review, 3, 1-38.

Briffa, M., \& Sneddon, L. U. (2010). Contest behavior. In D. F. Westneat \& C. Fox (Eds.), Evolutionary behavioral ecology (pp. 246-266). Oxford University Press.

Candia, R., Puig, S., Dalmasso, A., Videla, F., \& Martínez Carretero, E. (1993). Diseño del Plan de Manejo para la reserva provincial La Payunia (Malargüe, Mendoza). Multequina, 2, 5-87.

Caraco, T. (1979). Time budgeting and group size: A test of theory. Ecology, 60(3), 618-627. https://doi.org/10.1038/news050808-1

Carmanchahi, P. D., Panebianco, A., Leggieri, L., Barri, F., Marozzi, A., Flores, C., Moreno, P., Schroeder, N., Cepeda, C., Oliva, G., Kin, M. S., Gregorio, P., Ovejero, R., Acebes, P., Schneider, C. F., Pedrana, J., \& Taraborelli, P. (2019). Lama guanicoe. In: SAyDS-SAREM (eds.) Categorización 2019 de los mamíferos de Argentina según su riesgo de 
extinción. Lista Roja de los mamíferos de Argentina. Retrieved from http://cma.sarem.org.ar/es/especie-nativa/lama-guanicoe

Cavigelli, S. A., \& Pereira, M. E. (2000). Mating season aggression and fecal testosterone levels in male ring-tailed lemurs (Lemur catta). Hormones and Behavior, 37, 246-255. https://doi.org/10.1006/hbeh.2000.1585

Clutton-Brock, T., \& Albon, S. (1979). The roaring of red deer and the evolution of honest advertisement. Behaviour, 69, 145-170. https:// doi.org/10.1163/156853979X00449

Clutton-Brock, T. H., Albon, S. D., Gibson, R. M., \& Guinness, F. E. (1979). The logical stag: Adaptive of fighting in red deer (Cervus elaphus L.). Animal Behaviour, 27, 221-225.

Clutton-Brock, T. H., Guinness, F. E., \& Albon, S. D. (1982). Red deer: Behavior and ecology of two sexes. University of Chicago Press.

Corlatti, L., Caroli, M., Pietrocini, V., \& Lovari, S. (2013). Rutting behaviour of territorial and nonterritorial male chamois: Is there a home advantage? Behavioural Processes, 92(2010), 118-124. https://doi. org/10.1016/j.beproc.2012.11.008

Daget, P., \& Poissonet, J. (1971). Une méthode d'analyse phytologique des prairies; cniteres d'application. Annales Agronomiques, 22(1), $5-41$.

Emlen, S. T., \& Oring, L. W. (1977). Ecology, sexual selection, and the evolution of mating systems. Science, 197(4300), 215-223. https:// doi.org/10.1126/science.327542

Enquist, M., \& Leimar, O. (1987). Evolution of fighting behaviour: The effect of variation in resource value. Journal of Theoretical Biology, 127(2), 187-205. https://doi.org/10.1016/S0022-5193(87)80130-3

Enquist, M., Plane, E., \& Roed, J. (1985). Aggressive communication in fulmars (Fulmarus glacialis) competing for food. Animal Behaviour, 33, 1007-1020. https://doi.org/10.1016/S0003-3472(85)80035-X

Fattorini, N., Brunetti, C., Baruzzi, C., Macchi, E., Pagliarella, M. C., Pallari, N., Lovari, S., \& Ferretti, F. (2018). Being "hangry": Food depletion and its cascading effects on social behaviour. Biological Journal of the Linnean Society, 125, 640-656. https://doi.org/10.1093/biolinnean/bly119

Fattorini, N., Lovari, S., Brunetti, C., Baruzzi, C., Cotza, A., Macchi, E., Pagliarella, M. C., \& Ferretti, F. (2018). Age, seasonality, and correlates of aggression in female Apennine chamois. Behavioral Ecology and Sociobiology, 72(10), 171. https://doi.org/10.1007/s0026 5-018-2584-5

Festa-Bianchet, M., Apollonio, M., Mari, F., \& Rasola, G. (1990). Aggression among lekking male fallow deer (Dama dama): Territory effects and relationship with copulatory success. Ethology, 85, 236246. https://doi.org/10.1111/j.1439-0310.1990.tb00403.x

Fox, J., \& Monette, G. (1992). Generalized collinearity diagnostics. Journal of the American Statistical Association, 87(417), 178-183. https://doi. org/10.1080/01621459.1992.10475190

Fox, J., \& Weisberg, S. (2019). An R companion to applied regression. 3rd ed. SAGE.

Franklin, W. L. (1982). Biology, ecology and relationship to man of the South American camelids. In M. A. Marer \& H.-H. Genoways (Eds.), Mammalian biology in South America (pp. 457-489). University of Pittsburgh.

Franklin, W. (1983). Contrasting socioecologies of South America's wild camelids: The vicuña and the guanaco. Advances in the Study of Mammalian Behavior, 7, 573-629.

Franklin, W. L., \& Fritz, M. A. (1991). Sustained harvesting of the Patagonia guanaco: Is it possible or too late? In: J. G. Robinson \& K. H. Redford (Eds.), Neotropical wildlife use and conservation (pp. 317-336). University of Chicago Press.

Fritz, M. A. (1985). Population dynamics and harvestability of the Patagonian guanaco, M.Sc. Thesis. lowa State University.

Fryxell, J. M. (1987). Lek breeding and territorial aggression in white-eared kob. Ethology, 75, 211-220. https://doi. org/10.1111/j.1439-0310.1987.tb00654.x

Geist, V. (1978). Life strategies, human evolution, environmental design: Toward a biological theory of health. Springer-Verlag.
Gelman, A., Su, Y.-S., Yajima, M., Hill, J., Pittau, M. G., Zheng, J. K. T., \& Dorie, V. (2018). Data analysis using regression and multilevel/hierarchical models.

González, B. A., Palma, R. E., Zapata, B., \& Marin, J. C. (2006). Taxonomic and biogeographical status of guanaco Lama guanicoe (Artiodactyla, Camelidae). Mammal Review, 36, 157-178. https://doi. org/10.1111/j.1365-2907.2006.00084.x

Goss-Custard, J. D., Clarke, R. T., \& le V. dit Durell, S. E. A., (1984). Rates of food intake and aggression of oystercatchers Haematopus ostralegus on the most and least preferred mussel mytilus edulis beds of the exe estuary. The Journal of Animal Ecology, 53(1), 233. https://doi. org/10.2307/4354

Gregorio, P. F., Panebianco, A., Ovejero Aguilar, R., Taraborelli, P. A., Moreno, P. G., Schroeder, N. M., Leggieri, L. R., Marozzi, A. A., \& Carmanchahi, P. D. (2019). Linking diet quality and energy demand in free-living guanacos: An eco-physiological innovative approach. Journal of Zoology, 308(4), 243-252. https://doi.org/10.1111/ jzo.12667

Harrison, X. A. (2014). Using observation-level random effects to model overdispersion in count data in ecology and evolution. PeerJ, 2, e616. https://doi.org/10.7717/peerj.616

Hoem, S. A., Melis, C., Linnell, J. D. C., \& Andersen, R. (2007). Fighting behaviour in territorial male roe deer Capreolus capreolus: The effects of antler size and residence. European Journal of Wildlife Research, 53(1), 1-8. https://doi.org/10.1007/s10344-006-0053-3

Huntingford, F., \& Turner, A. (1987). Animal conflict (D. M. Broom \& P. W. Colgan, Eds.). Chapman \& Hall.

Jennings, D. J., \& Gammell, M. P. (2013). Contest behaviour in ungulates. In I. Hardy \& M. Briffa (Eds.), Animal Contests (pp. 304-320). Cambridge: Cambridge University Press. https://doi.org/10.1017/ CBO9781139051248.016

Jennings, D. J., Gammell, M. P., Carlin, C. M., \& Hayden, T. J. (2004). Effect of body weight, antler length, resource value and experience on fight duration and intensity in fallow deer. Animal Behaviour, 68, 213-221. https://doi.org/10.1016/j.anbehav.2003.11.005

Jurgensen, T. (1985). Seasonal territoriality in a migratory guanaco population, M.Sc. Thesis. lowa State University.

Kitchen, D. W. (1974). Social behavior and ecology of the pronghorn. Wildlife Monographs, 38, 3-96. https://doi.org/10.2307/3830497

Knell, R. J. (2009). Population density and the evolution of male aggression. Journal of Zoology, 278(2), 83-90. https://doi. org/10.1111/j.1469-7998.2009.00566.x

Koenig, A., Larney, E., Lu, A., \& Borries, C. (2004). Agonistic behavior and dominance relationships in female phayre's leaf monkeys Preliminary results. American Journal of Primatology, 64(3), 351-357. https://doi.org/10.1002/ajp.20084

Korner-Nievergelt, F., Roth, T., von Felten, S., Guélat, J., Almasi, B., \& Korner-Nivergelt, P. (2015). Bayesian data analysis in ecology using linear models with R. BUGS, and Stan. https://doi.org/10.1007/s1339 8-014-0173-7.2

Lane, S. M., \& Briffa, M. (2018). How does the environment affect fighting? The interaction between extrinsic fighting ability and resource value during contests. Journal of Experimental Biology, 221, jeb187740. https://doi.org/10.1242/jeb.187740

Lovari, S., Fattorini, N., Boesi, R., \& Bocci, A. (2015). Male ruff colour as a rank signal in a monomorphic-horned mammal: Behavioural correlates. The Science of Nature, 102, 39. https://doi.org/10.1007/s0011 4-015-1290-7

Lucherini, M. (1996). Aggressive behaviour in free-ranging guanacos and vicuñas in Argentina. Aggressive Behavior, 22, 289-296. https://doi. org/10.1002/(SICI)1098-2337(1996)22:4<289:AID-AB4>3.0.CO;2-G

Maher, C. R. (2000). Quantitative variation in ecological and hormonal variables correlates with spatial organization of pronghorn (Antilocapra americana) males. Behavioral Ecology and Sociobiology, 47(5), 327-338. https://doi.org/10.1007/s002650050673 
Marino, A. (2012). Indirect measures of reproductive effort in a resource-defense polygynous ungulate: Territorial defense by male guanacos. Journal of Ethology, 30(1), 83-91. https://doi.org/10.1007/s10164-011-0299-4

Marino, A., \& Baldi, R. (2008). Vigilance patterns of territorial guanacos (Lama guanicoe): The role of reproductive interests and predation risk. Ethology, 114, 413-423. https://doi. org/10.1111/j.1439-0310.2008.01485_1.x

Martin, P., \& Bateson, P. (2007). Measuring behaviour. An introductory guide. 3rd ed. Cambridge University Press.

Martínez Carretero, E. (2004). La Provincia Fitogeográfica de la Payunia. Boletín De La Sociedad Argentina De Botánica, 39, 195-226.

Matteucci, S. D., \& Colma, A. (1982). Metodología para el estudio de la vegetación. Secretaría General de la Organización de los Estados Americanos (OEA). Programa Regional de Desarrollo Científico y Tecnológico.

Maynard Smith, J. (1982). Evolution and the theory of games. Cambridge University Press.

McCullagh, P., \& Nelder, J. (1989). Generalized linear models. Chapman and Hall/CRC.

Mohr Bell, D., \& Siebert, A. (2008). Monitoreo de la sequía en la provincia del Chubut. Esquel.

Moyer, K. E. (1968). Kinds of aggression and their physiological basis. Communications in Behavioral Biology, Part A, 2, 65-87.

Mulero-Pázmány, M., Jenni-Eiermann, S., Strebel, N., Sattler, T., Negro, J. J., \& Tablado, Z. (2017). Unmanned aircraft systems as a new source of disturbance for wildlife: A systematic review. PLoS One, 12(6), 114. https://doi.org/10.1371/journal.pone.0178448

Murray, M. G. (1982). The rut of impala: Aspects of seasonal mating under tropical conditions. Zeitschrift Für Tierpsychologie, 59(4), 319337. https://doi.org/10.1111/j.1439-0310.1982.tb00345.x

Nelson, R. J. (2006). Biology of aggression. Biology of Aggression, https:// doi.org/10.1093/acprof:oso/9780195168761.001.0001

Ortega, I. M. (1985). Social organization and ecology of a migratory guanaco population in southern Patagonia, M.Sc. Thesis. Iowa State University.

Ortega, I. M., \& Franklin, W. L. (1995). Social organization, distribution and movements of a migratory guanaco population in the Chilean Patagonia. Revista Chilena De Historia Natural, 68, 489-500.

Ostner, J., Kappeler, P. M., \& Heistermann, M. (2002). Seasonal variation and social correlates of androgen excretion in male redfronted lemurs (Eulemur fulvus rufus). Behavioral Ecology and Sociobiology, 52(6), 485-495. https://doi.org/10.1007/s00265-002-0532-9

Ovejero, R., Jahn, G. A., Soto-Gamboa, M., Novaro, A., \& Carmanchahi, P. D. (2016). The ecology of stress: Linking life-history traits with physiological control mechanisms in free-living guanacos. PeerJ, 4, e2640. https://doi.org/10.7717/peerj.2640

Panebianco, A. (2019). Aspectos comportamentales y fisiológicos involucrados en la sociabilidad de guanacos silvestres. [Doctoral dissertation, University of Buenos Aires]. Retrieved from https://core.ac.uk/ download/pdf/223030415.pdf

Panebianco, A., Gregorio, P., Ovejero, R., Marozzi, A., Leggieri, L. R., Taraborelli, P. A., \& Carmanchahi, P. (2020). Reproductive flexibility in South American camelids: first records of alternative mating tactics in wild guanacos (Lama guanicoe). Mastozoología Neotropical, 27(1), 200-205. https://doi.org/10.31687/saremMN.20.27.1.0.23

Parker, G. A. (1974). Assessment strategy and the evolution of fighting behaviour. Journal of Theoretical Biology, 47, 223-243. https://doi. org/10.1016/0022-5193(74)90111-8

Payne, R. J. H., \& Pagel, M. (1997). Why do animals repeat displays ? Animal Behaviour, 54, 109-119. https://doi.org/10.1006/anbe.1996.0391

Pereira, R. J. G., Duarte, J. M. B., \& Negrão, J. A. (2005). Seasonal changes in fecal testosterone concentrations and their relationship to the reproductive behavior, antler cycle and grouping patterns in free-ranging male Pampas deer (Ozotoceros bezoarticus bezoarticus). Theriogenology, 63(8), 2113-2125. https://doi.org/10.1016/j.theri ogenology.2004.08.014
Pettorelli, N., Vik, J. O., Mysterud, A., Gaillard, J.-M., Tucker, C. J., \& Stenseth, N. C. (2005). Using the satellite-derived NDVI to assess ecological responses to environmental change. Trends in Ecology \& Evolution, 20(9), 503-510. https://doi.org/10.1016/J. TREE.2005.05.011

Piersma, T., \& Drent, J. (2003). Phenotypic flexibility and the evolution of organismal design. Trends in Ecology and Evolution, 18, 228-233. https://doi.org/10.1016/S0169-5347(03)00036-3

Puig, S., Videla, F., \& Cona, M. I. (1997). Diet and abundance of the guanaco (Lama guanicoe, Muller 1776) in four habitats of northern Patagonia, Argentina. Journal of Arid Environments, 36(2), 343-357. https://doi.org/10.1006/jare.1996.0186

Puig, S., Videla, F., Monge, S., \& Roig, V. (1996). Seasonal variations in guanaco diet (Lama guanicoe Müller 1776) and food availability in Northern Patagonia, Argentina. Journal of Arid Environments, 34, 215-224. https://doi.org/10.1006/jare.1996.0103

R Core Team. (2016). $R$ : A language and environment for statistical computing, 55, 275-286. Retrieved from http://www.R-project.org

Raedeke, K. (1979). Population dynamics and socioecology of the guanaco (Lama guanicoe) of Magallanes, Chile. PhD Thesis. University of Washington College of Forest Resources.

Reed, B. C., Brown, J. F., VanderZee, D., Loveland, T. R., Merchant, J. W., \& Ohlen, D. O. (1994). Measuring phenological variability from satellite imagery. Journal of Vegetation Science, 5(5), 703-714. https://doi. org/10.2307/3235884

Romero, L. M., Dickens, M. J., \& Cyr, N. E. (2009). The reactive scope model - A new model integrating homeostasis, allostasis, and stress. Hormones and Behavior, 55(3), 375-389. https://doi.org/10.1016/j. yhbeh.2008.12.009

Schroeder, N. M., Matteucci, S. D., Moreno, P. G., Gregorio, P., Ovejero, R., Taraborelli, P., \& Carmanchahi, P. D. (2014). Spatial and seasonal dynamic of abundance and distribution of guanaco and livestock: Insights from using density surface and null models. PLoS One, 9(1), https://doi.org/10.1371/journal.pone.0085960

Sirot, E. (2000). An evolutionarily stable strategy for aggressiveness in feeding groups. Behavioral Ecology, 11(4), 351-356. https://doi. org/10.1093/beheco/11.4.351

Stookey, J. M., \& Gonyou, H. W. (1994). The effects of regrouping on behavioral and production parameters in finishing swine. Journal of Animal Science, 72, 2804-2811.

Taillon, J., \& Côté, S. D. (2007). Social rank and winter forage quality affect aggressiveness in white-tailed deer fawns. Animal Behaviour, 74(2), 265-275. https://doi.org/10.1016/j.anbehav.2006.11.018

Taraborelli, P., Gregorio, P., Moreno, P., Novaro, A., \& Carmanchahi, P. D. (2012). Cooperative vigilance: The guanaco's (Lama guanicoe) key antipredator mechanism. Behavioral Processes, 91, 82-89. https://doi. org/10.1016/j.beproc.2012.06.002

Teichroeb, J. A., \& Sicotte, P. (2008). Social correlates of fecal testosterone in male ursine colobus monkeys (Colobus vellerosus): The effect of male reproductive competition in aseasonal breeders. Hormones and Behavior, 54(3), 417-423. https://doi.org/10.1016/j. yhbeh.2008.04.006

Ungerfeld, R., \& Freitas-de-Melo, A. (2014). Pampas deer (Ozotoceros bezoarticus) male-female agonistic behavior toward high and low social ranked females. Acta Ethologica, 17, 167-171. https://doi. org/10.1007/s10211-013-0178-9

Van der Wal, R., Madan, N., van Lieshout, S., Dormann, C., Langvatn, R., \& Albon, S. D. (2000). Trading forage quality for quantity? Plant phenology and patch choice by Svalbard reindeer. Oecologia, 123(1), 108-115. https://doi.org/10.1007/s004420050995

Vander Wal, E., Yip, H., \& McLoughlin, P. D. (2012). Sex-based differences in density-dependent sociality: An experiment with a gregarious ungulate. Ecology, 93(1), 206-212. https://doi.org/10.1890/11-0020.1

Vilá, B. (1992). Vicuñas (Vicugna vicugna) agonistic behavior during the reproductive season. In F. Spitz, G. Janeau, G. González, \& 
S. Aulagnier (Eds.), Ungulates 91, Proceedings of the International Symposium (pp. 475-482). Toulouse.

Villagrán, M., Freitas-de-Melo, A., Bartoš, L., \& Ungerfeld, R. (2020). Aggressive interactions among female, semi-captive pampas deer (Ozotoceros bezoarticus) increase within the hierarchy and after short-term removal of the male. Aggressive Behavior, 46, 181-187. https://doi.org/10.1002/ab.21880

West, P., \& Packer, C. (2002). Sexual selection, temperature, and the lion's mane. Science, 297, 1339-1343. https://doi.org/10.1126/scien ce.1073257

Willisch, C. S., \& Neuhaus, P. (2010). Social dominance and conflict reduction in rutting male Alpine ibex, Capra ibex. Behavioral Ecology, 21(2), 372-380. https://doi.org/10.1093/beheco/arp200

Wilson, P. E. (1982). An analysis of male-male aggression in guanaco male groups, M.Sc. Thesis. lowa State University.

Wilson, P., \& Franklin, W. L. (1985). Male group dynamics and inter-male aggression of guanaco in Southern Chile. Zeitschrift Tierpsychologie, 69, 305-328.

Wingfield, J. C., Ball, G. F., Dufty, A. M. Jr, Hegner, R. E., \& Ramenofsky, M. (1987). Testosterone and Aggression in Birds. American Scientist, 75(6), 602-608. https://doi.org/10.1016/0008-8846(84)90086-3

Wingfield, J. C., Lynn, S. E., \& Soma, K. K. (2001). Avoiding the "costs" of testosterone: Ecological bases of hormone-behavior interactions. Brain, Behavior and Evolution, 57(5), 239-251. https://doi. org/10.1159/000047243

Wingfield, J., Moore, I., Goymann, W., Wacker, D. W., \& Sperry, T. (2006). Contexts and ethology of vertebrate aggression: Implications for the evolution of hormone-behavior interactions. In R. J. Nelson (Ed.), Biology of aggression (pp. 179-274). Oxford University Press.
Young, J. K., \& Franklin, W. L. (2004a). Activity budget patterns in family-group and solitary territorial male guanacos. Revista Chilena de Historia Natural, 77, 617-625. https://doi.org/10.4067/S0716-078X2 004000400005

Young, J. K., \& Franklin, W. L. (2004b). Territorial Fidelity of male guanacos in the Patagonia of Southern Chile. Journal of Mammalogy, 85(1), 72-78. https://doi.org/10.1644/1545-1542(2004)085<0072:TFOMGI $>2.0 . \mathrm{CO} ; 2$

Zahavi, A. (1987). The theory of signal selection and some of its implications. In V. Delfino (Ed.), International symposium of biological evolution (pp. 305-327). Adriatica Editrice.

Zumpe, D., \& Michael, R. P. (2001). Notes on the elements of behavioral science. Springer.

Zuur, A. F., leno, E. N., \& Smith, G. M. (2007). Analysing ecological data. Springer.

\section{SUPPORTING INFORMATION}

Additional supporting information may be found online in the Supporting Information section.

How to cite this article: Panebianco A, Gregorio PF, Ovejero

$\mathrm{R}$, et al. Male aggressiveness in a polygynous ungulate varies with social and ecological context. Ethology. 2020;00:1-15. https://doi.org/10.1111/eth.13100 